\title{
Later Life Moves and Movers in Germany: An Expanded Typology
}

\section{Tim Winke}

\begin{abstract}
In times of ageing baby boomer cohorts and increasing regional disparities, residential choice in later life is important regarding family relations and the provision of social services. In this study, a new typology of later life moves is developed based on observed patterns and characteristics of residential changes. For this purpose, the German Socio-Economic Panel data has been linked to uniquely detailed neighbourhood information to study how aspects of both later life movers and moves are structured. The results suggest four types of moves, namely: residential improvement, family, residential adaptation and care moves. The typology expands rigid classifications based on age, health status or distance moved, and highlights intergenerational family ties, housing concerns and fragmented forms of partnership as key aspects. Family moves to one's children are associated with the existence of grandchildren, showing that elderly people take on roles as both care-takers and care-providers. The residential consequences of being widowed or divorced are socially stratified and can lead to residential and economic instability.
\end{abstract}

Keywords: Later life migration · Residential mobility · Life course · Germany · Nonnegative matrix factorisation

\section{Introduction}

With a median age of 46.2 years in 2015 , Germany's population has become the second oldest in the world and is forecast to age further in the upcoming decades (United Nations 2015). Demographic ageing is not distributed equally across regions. From 2001 to 2006, rural areas in Germany have experienced the largest increase in the share of elderly people, while urban areas mostly gained in the share of younger cohorts (Go// 2010). This is reflected in the geographic distance between family members. The share of adult children living in the same town as their parents has decreased significantly from 38 percent in 1996 to 26 percent in 2014 (Mahne/ 
Huxhold 2017). A concentration of ageing and population decline in rural regions may alter family relations and poses challenges regarding the provision of social services and health care (Swiaczny 2010). The questions of who moves where, and why, during later life are pressing in times of ageing baby boomer cohorts and increasing regional disparities. However, residential behaviour of the elderly differs from employment-related migration in terms of its determinants and spatial patterns (Litwak/Longino 1987).

This study provides insights into the heterogeneity of later life migration in Germany. In an exploratory part, non-negative matrix factorisation is employed as a cluster method to find patterns in later life moves. Next, multinomial logistic regression helps assess the relative importance of household characteristics for each type of move. The wide range of socio-economic and demographic information of the representative household survey, the German Socio-Economic Panel (SOEP), permits a deep understanding of the features of elderly movers and the characteristics of their moves. Distance measures to children and grandchildren enable an exploration of the role of intergenerational aspects, while small-scale neighbourhood characteristics show the influence of the regional context on the decision to move. The analysis reveals four types of later life moves: (i) residential improvement moves toward house-ownership and to higher status neighbourhoods in $2-50 \mathrm{~km}$ distance from the previous home, (ii) long-distance family moves towards children and grandchildren, (iii) residential adaptation moves within urban neighbourhoods to rental apartments and social housing and (iv) care moves to nursing homes or accessible housing usually linked to a decrease in neighbourhood and housing satisfaction.

This analysis adds to previous work and structures later life moves in several ways. First, a representative household panel survey - rather than aggregated data - is employed, including detailed intergenerational and neighbourhood information. Life course and neighbourhood factors have been found to be interrelated in the decision to move (Feijten/van Ham 2009; Boschman/van Ham 2015). Changes in either context might lead to residential stress and a mismatch between locational preferences and the environment (Rossi 1955; Brown/Moore 1970). Second, nonnegative matrix factorisation as a novel clustering algorithm allows for the exploration of patterns in the observed data without pre-specifying moving types ex-ante. Third, the two-step analytical approach helps to relate patterns of later life moves with characteristics of households. This way, a comprehensive picture is provided about who is likely to move in a specific way.

\section{Background}

Research on later life migration studies the relocation behaviour and migration patterns around and during retirement. This has yielded varying concepts and terminologies over the past decades (see Sander et al. 2010; Goll 2010).

In their seminal work, Litwak and Longino (1987) structure later life moves into three types: First, a long-distance move around retirement age to benefit from lo- 
cal amenities, e.g. warmer climate, fostering friendship networks or living closer to one's place of birth. Such moves are associated with individuals close to leaving the workforce who are rather healthy, financially independent, and married. The second type of move involves relocating to a place closer to children as primary care-giver. They are associated with older, and often widowed, retirees in deteriorating health conditions that make everyday tasks difficult. Institutional substitutes, neighbours or same-age friends are essential at this stage, but might lack commitment and expertise to provide adequate long-term care. The third type is triggered by severe disabilities and a high level of required assistance. Very old people at this stage are likely to move to institutional care facilities.

The three-stage model summarises regularities found in later life migration and has become one of the most prominent taxonomies in this regard. Despite its consecutive nature, a specific household must neither go through all three stages, nor follow the timing of moves. Rather, the model embeds the migration decision of elderly households in health, partnership and family developments over life stages. Empirical assessments of the three-stage model have mainly focused on U.S. contexts and employed aggregated census data (Litwak/Longino 1987; Bradley 2011). They find a higher share of widowers, disabled and very old people who leave prominent retirement destinations compared to those who enter.

The three-stage model by Litwak and Longino (1987) can be criticised for its lack of insights into the actual decision-making process, e.g. migration as a household decision (Brown/Moore 1970), the role of gender and power (De Jong 2000), and the interdependencies among moving opportunities, social networks and life course events (Kley 2011). As argued by Bloem et al. (2008), there is no single way from one life event to a particular mobility outcome. For example, health problems in the second stage might themselves be less important for a move but could be mediated by the loss of a spouse (Mulder/Hooimeijer 1999).

The life course perspective explicitly incorporates the interconnected role of life trajectories within and between individuals (Elder et al. 2003). Life events in one domain might trigger changes in other domains, such as a job opportunity in another city or the birth of a child. In life course studies, residential behaviour of individuals is embedded in the socio-historical context and the timing of life events (Rindfuss et al. 1987). For example, changes in the career or family domain might trigger moves conditional upon the prevailing norms and economic situation in a household's region (Dieleman et al. 2000). Life course events of individuals affect the decisions of family members and friends, which implies an adaptation and synchronisation of life plans. The relation of life events and living contexts has also been highlighted for retirement moves, i.e. moves around the time individuals leave the workforce. For Australia, Sander and Bell (2014) found that the effect of entering retirement as a trigger for moving is mitigated if the spouse has not exited the workforce.

Mulder and Hooimeijer (1999) attempt to disentangle determinants of migration by distinguishing triggers and conditions of moving. Triggers describe changes in life domains such as a divorce or an empty nest stage. Life domains such as education, the labour market, household composition, housing situations and health are assumed to interact with and moderate triggers. For example, the birth of a child 
might trigger a move in the family domain, but the move is hampered by financial constraints. An advantage of the model is its flexibility regarding the interactions of life domains and life events leading to the decision to move. However, this comes at the cost of not providing testable narratives on how socio-cultural circumstances specifically influence individuals and how they shape the meanings of triggers and conditions.

This paper examines patterns and determinants of later life moves and movers in Germany. The underlying theoretical approach rests on earlier typologies, most notably the lifestyle, comfort and care move framework by Litwak and Longino (1987) and findings from life course research on mobility (i.a. Mulder/Hooimeijer 1999). The three-stage model is not explicit about the range of applicability in space and time, but is largely shaped by the U.S. experience in the 1970s and 1980s. In contrast to the U.S., the geographical size of Germany is much smaller and the country has less climatic differences. Germany is regarded as having a more egalitarian and conservative welfare regime, which implies stronger workers' rights, lower income imbalances and universal health and care provision (Hall/Soskice 2001). The above factors are likely to have a dampening effect on later life migration. For example, Friedrich (1995) shows that Germany's elderly population shows a stronger attachment to their place of living and less locational flexibility than in the U.S.

Germany shares socio-demographic trends apparent in many Western countries with respect to marriage, fertility and societal change (Cherlin 2010; Lesthaeghe 2010). Referring to the literature on life course transitions, the concepts of destandardisation and pluralism describe a shift towards heterogeneous and individualistic trajectories in the family and career domains (Amrhein 2004; Frick et al. 2012). Partnerships have become more fragmented, along with the heightened postponement of marriages and increasing divorce rates and unmarried cohabitations (Bumpass/ Lu 2000; Cliquet 2003). Liberal gender roles have led to more diverse career paths of women while the male breadwinner model has become less and less common (Simonson et al. 2011).

With respect to the life course approach on mobility, the notion of individuals' agency is emphasized in this study, while constrained by norms, institutions and the local environment. Further, the idea of linked lives states that decisions of individuals are affected by, and can in turn affect, other people's life courses (Elder et al. 2003). For the analysis, this implies (i) that households are taken as the primary unit of analysis, (ii) that the socio-demographic context of households is considered, including their neighbourhood and extended family and (iii) that recent partnership events are distinguished from long-term partnership conditions as triggers for moving.

\section{Analytical approach}

The aim of the study is to structure the heterogeneity of later life movers and to examine their determinants for moving. For this purpose, representative longitudinal survey data for Germany is merged with detailed regional information. 
The analytical strategy of the paper is twofold. First, the cluster analysis aims at finding patterns solely in the characteristics of moves. For this, subjective and objective measures that characterise moves are clustered. In a second step, multinomial regression analysis evaluates the relative importance of household characteristics for each type of move.

The approach allows for a flexible assessment of empirical moving patterns without classifying moves ex-ante. The dependent variable is the type of move as derived from the cluster analysis. Employing the resulting cluster as moving outcomes enables linking characteristics of households to specific moving types. The base outcome is no change in address between two survey years. Because relocation is generally regarded as a household decision (Brown/Moore 1970; De Jong/ Fawcett 1981), the household is the level of analysis for this study.

\subsection{Data and measures}

The SOEP is a longitudinal household survey which started in West Germany in 1984 and was extended to East Germany in 1990, after reunification. It is the largest panel survey in Germany, with yearly interviews of around 20,000 individuals in 12,000 households (Kroh 2014). For this study, the waves from 2001 to 2013 are employed, covering a total of 10,267 households aged 55 and older. A person drops out of the SOEP study if he or she dies, refuses participation or leaves Germany. Individuals are not excluded if they move within Germany or enter institutionalised care. Individuals enter the sample population when they join an existing household by birth or cohabitation, if a new subsample is initiated or a previous subsample is extended.

For this study, small-scale neighbourhood information is linked to the SOEP panel data. The micromarketing company MICROM provides geographic information about a neighbourhood's socio-economic structure, construction types and migration patterns. Street-level data is generated by aggregating information of neighbouring households from different public and proprietary data sources.

The starting points for the selection of variables for the cluster and regression analysis are the three-stage model of later life migration and the life course perspective on mobility. The former emphasizes the partnership and health contexts of a household in the decision to move. The latter acknowledges the inter-dependencies of life trajectories within and between family members. Trajectories are shaped by past events - such as the residential place of childhood - while being embedded in current institutional, historic and spatial contexts (Courgeau 1995). Two different sets of variables are used for each step of the analysis. While the first part incorporates variables that characterise a move subjectively and objectively, the second part focusses on attributes of households. Tables 1 and 2 list all variables used in the cluster and regression analysis.

The first part aims at determining types of later life moves. A later life move is defined as a change in address between two survey years of households whose head or spouse, if any, is age 55 or older. The subsample for the cluster analysis consists 
of 1,654 later life moves made by 1,145 households between 2001 and 2013. The considered cluster variables characterise the moving behaviour both structurally and subjectively. Structural characteristics include moving distance, changes in floor space, moving closer to family members, buying a house, renting an apartment, moving back to the place of childhood, to an elderly home or social housing as well as moving to or from urban/rural regions. Subjective measures include reasons for moving such as family, housing or job reasons as well as a household's housing and neighbourhood situation before and after a move.

The distance of moves is available in kilometres and split into three classes: short-distance moves of $2 \mathrm{~km}$ and less, medium-distance moves between $2 \mathrm{~km}$ and $50 \mathrm{~km}$ and long-distance moves of $50 \mathrm{~km}$ and more. Daily interactions with people in the former place of residence are presumably difficult to maintain beyond $50 \mathrm{~km}$ (see Lundholm 2015). External neighbourhood information derives from MICROM data and covers an upgrade or downgrade in the neighbourhood status and its share of migrants. For the analysis, a neighbourhood has a high share of migrants if it exceeds 25 percent (approx. at the 80th percentile). The number of and spatial distance to parents, children and grandchildren are recorded every five years starting from 1991. Downward cascading is employed to fill in missing values while taking residential changes into account. Having family members nearby equals one if either the household head or partner or both have parents, children or grandchildren living in in the same town, and zero otherwise. A move to children occurs if a household has not lived in the same town as their children but does so after a move.

The second part of the analysis focusses on how characteristics in the life domains of family, career, housing and health of a household are related to each type of move. It includes (a) demographic variables such as the age of the oldest household partner, migration background and partnership status, (b) variables related to the professional background such as years of education, household income and long-term unemployment experience of any household partner, (c) inter-generational variables such as the existence of children and hours spent on childcare on an average weekday, (d) the previous housing situation such as home-ownership and years lived in the current residence and (e) health indicators.

The partnership and workforce status were retrospectively surveyed and cover the time before a person entered the survey. Partnership status can either be married (reference group), married in the past two years, divorced, divorced in the past two years, widowed, widowed in the past two years or unmarried. This way, conditions and recent changes in the partnership domain can be assessed as triggers for moving. The workforce indicator has three levels: (a) household head or partner employed (reference group), (b) household head and partner unemployed/retired in the last two years and (c) household head and partner unemployed or retired for more than two years. The health condition is captured in two ways: first, as a statement about perceived health ranging from 0 to 10, and second, by the level of being legally disabled ranging from 0 to 100 percent. In the case of cohabitation with a spouse, the maximum disabled value of the two partners and the minimum value in perceived health is used. The net household income is adjusted by the yearly purchasing power and weighted by household size (Grabka 2012). 
The sample for the regression consists of 64,214 yearly observations of 10,267 households aged 55 and older. Year-specific household weights are applied to capture the probability of being selected into the SOEP sample and to account for attrition over time (Kroh 2014). Attrition in longitudinal surveys is sensitive to residential changes. Households might be difficult to contact due to residential moves in the year of their move. Missing values for years where no data was collected $(n=40)$ are replaced by information from the following survey year.

\subsection{Methods}

Non-negative matrix factorisation (NMF) is an unsupervised learning technique that has been applied successfully in text analysis, market research, face recognition and bioinformatics (see Wang/Zhang 2013). The idea of NMF is to factorise the target matrix $\mathrm{V}$ with $\mathrm{n}$ observations and o covariates into two matrices of lower rank, the basis matrix $\mathrm{W}$ and the mixture effect matrix $\mathrm{H}$ (see Fig. 1). In an iterative process starting from a random assignment, the latter two matrices are chosen such that their product approximates the target matrix $\mathrm{V}$ best.

NMF has been shown to perform very well in the identification of clusters (Hutchins et al. 2008; Frigyesi/Höglund 2008) and has some key advantages over other clustering algorithms: First, the resulting components have an intuitive interpretation. The k columns of the basis matrix can be interpreted as latent groups that derive from the observed data, for example, individuals who share similar dispositions and preferences. This results from the constraint that the original data is only allowed to have non-negative values. Second, NMF allows clusters to overlap. Observation and covariates can both be associated with several clusters at once.

Fig. 1: Non-negative matrix factorisation
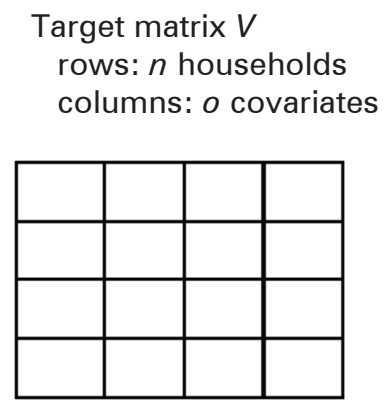

Basis matrix $W$ rows: $n$ households columns: $k$ clusters

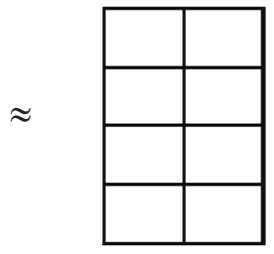

Mixture effect matrix $H$ rows: $k$ clusters columns: $o$ covariates

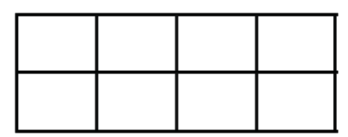

Notes: Illustration of non-negative matrix factorisation when 2 clusters are assumed (rank $\mathrm{k}=2$ ): the target matrix $\mathrm{V}$ is factorised into matrix $\mathrm{W}$ - indicating by how much households are represented in each cluster scaled from 0 to 1 - and matrix $\mathrm{H}$ - holding the mixture effect coefficients which indicate how strong covariates are associated with each cluster scaled from 0 to 1 . The objective of the algorithm is to find $\mathrm{W}$ and $\mathrm{H}$ such that their product approximates the target matrix $\mathrm{V}$ best.

Source: Own design 
The $\mathrm{n}^{*} \mathrm{k}$ elements of the basis matrix $\mathrm{W}$ indicate the extent to which observations are represented in each cluster. The $\mathrm{k}^{*} \mathrm{O}$ mixture effect matrix $\mathrm{H}$ provides a profile showing how strongly covariates are associated with each cluster. For this study, NMF is implemented using R Statistical Software 3.1.1 and the NMF package 0.20.5 by Gaujoux and Seoighe (2010). The subsample employed consists of households aged 55 and older in the year of their move $(n=1,654)$.

A critical step in the analysis is to specify the number of clusters ex-ante. A large number of clusters might result in better data approximation, but with the risk of overfitting. A small number of clusters reduces the complexity of the model but might neglect informative structures in the data. A common approach is to try a set of values and decide on the optimal number of cluster based on quality measures. A prominent measure for NMF analysis is the cophenetic correlation coefficient. It measures how stable observations are reassigned to the same clusters when running NMF multiple times. A coefficient of one indicates strong similarities while zero suggests completely scattered reassignments. To prevent overfitting, Brunet et al. (2004) recommend selecting the number of clusters before the cophenetic coefficient begins to fall. The analysis is run with the number of clusters $\mathrm{k}$ ranging from 3 to 7 . The cophenetic coefficient peaks at 4 clusters, which is the number of clusters presented below.

This cluster analysis helps to structure the characteristics of later life moves. In the second part of the analysis, the relative importance of household characteristics to move is evaluated using a multinomial regression model. The dependent variable equals the type of move as derived from the cluster analysis. The base outcome is no change in residence from one survey year to the next. The regression results are summarised as average marginal effects. Conditional on the observed predictors in the model, they depict the average difference in the predicted probability of moving with respect to the reference category. The effects are multiplied by 100 and interpreted as percentage point changes. Stata 14.0 is used for the analysis.

\subsection{Descriptive statistics}

Figure 2 displays the migration propensity over age for Germany between 2001 and 2013 , based on weighted SOEP data. Official German migration statistics are within the confidence interval of migration rates derived from the SOEP sample. The distribution replicates earlier findings of life course migration patterns in other countries (Rogers 1988; Clark/Onaka 1983; Yee/van Arsdol 1977). In particular, early-life migration has often been explained by family moves toward more spacious housing, while moves after adolescence are mostly associated with educational and lifestyle choices. Residential changes in the 30 s and 40 s are typically related to family formation and career aspirations, while care needs often trigger moves at later stages in

1 For official statistics on moves over German municipalities by age and gender in 2014 see: http://www.bib-demografie.de/EN/Facts_Figures/Internal_Migration/Figures/a_10_03_wanderungshaeufigkeit_gemeindegrenzen_alter_geschl_d_2014.html?nn=3215792 
Fig. 2: Residential changes over life-span for Germany

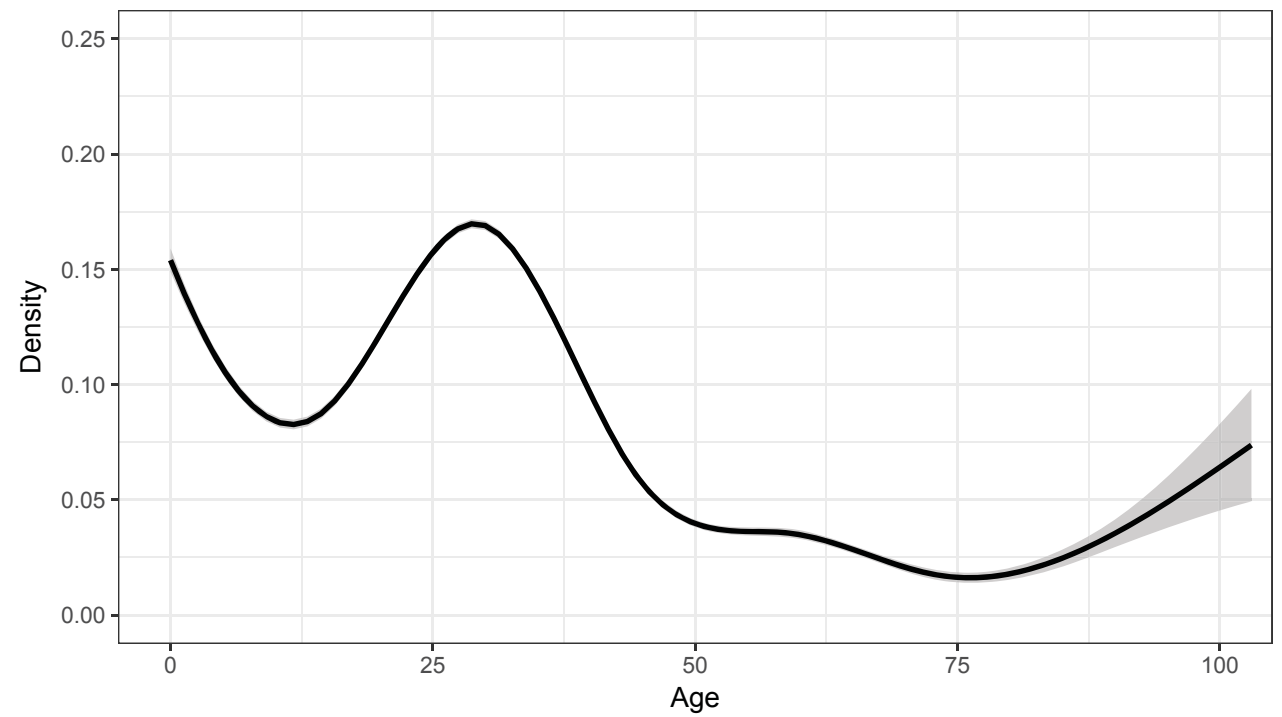

Notes: Generalised additive model with cubic smoothing of residential changes over age

Source: Own calculation, based on SOEP household members 2001-2013 (399,265 observations, person- and year-specific SOEP weights applied)

life (Mulder/Hooimeijer 1999). Retirement moves seem to occur not exclusively at the official retirement age of 65, but also several years before and after. Early retirement schemes and difficulties to re-enter the labour market for unemployed elderly people have led to an observed retirement age of 61 in 2010 (DRV 2015). On the other hand, pensioners might wait for their spouse to retire before moving (Sander) $B e / / 2014)$. Later life migration for Germany is highest for the age groups 50-59 and $80+$ (Angelini/Laferrere 2012).

Table 1 summarises the household variables used in the regression analysis for stayers and movers between two survey years over the observed period from 2001 to 2013. Means and shares are widely comparable between the two groups while differences exist in the partnership, housing and health domain. Almost half the stayers are married for more than two years; this is only the case for 36 percent of movers. Movers are 10 percentage points more likely to be divorced, 1 percentage points more likely to be recently separated, and 2 percentage points more likely to be recently widowed. Regarding the housing domain, movers are more likely to be tenants than owners before they move, and have typically spent fewer years in their previous residence. On average, movers are significantly younger according to a two-sided t-test (not shown) and have a higher degree of disability than stayers. This is independent of the cross-sectional year chosen for stayers and even applies if only movers in $2007(n=141)$ are considered. 
Tab. 1: Descriptive statistics

\begin{tabular}{|c|c|c|c|c|}
\hline & Min & Max & $\begin{array}{c}\text { Stayers } \\
\text { Mean (SD) or } \\
\text { shares }\end{array}$ & $\begin{array}{c}\text { Movers } \\
\text { Mean (SD) or } \\
\text { shares }\end{array}$ \\
\hline Age & 55 & 103 & $69.67(9.17)$ & $67.70(9.79)$ \\
\hline Migration background & 0 & 1 & 0.19 & 0.24 \\
\hline Married & 0 & 1 & 0.49 & 0.36 \\
\hline Married in past two years & 0 & 1 & 0.01 & 0.01 \\
\hline Divorced & 0 & 1 & 0.14 & 0.24 \\
\hline Divorced in past two years & 0 & 1 & 0.01 & 0.02 \\
\hline Widowed & 0 & 1 & 0.25 & 0.22 \\
\hline Widowed in past two years & 0 & 1 & 0.03 & 0.05 \\
\hline Unmarried & 0 & 1 & 0.08 & 0.09 \\
\hline Hours spent with childcare & 0 & 24 & $0.23(1.10)$ & $0.27(1.21)$ \\
\hline Never had children & 0 & 1 & 0.14 & 0.13 \\
\hline Annual Household income (Euro) & 5 & $2,041,514$ & $20,576(14,480)$ & $19,547(15,220)$ \\
\hline Years of education & 7 & 18 & $11.84(2.63)$ & $11.66(2.62)$ \\
\hline Years of unemployment & 0 & 37 & $0.68(1.97)$ & $1.01(2.46)$ \\
\hline Exit workforce & 0 & 1 & 0.62 & 0.55 \\
\hline Exit workforce in past two years & 0 & 1 & 0.05 & 0.08 \\
\hline Domicile owner prev year & 0 & 1 & 0.53 & 0.20 \\
\hline Years lived in residence & 0 & 96 & $25.48(18.40)$ & $16.73(16.02)$ \\
\hline Disability degree & 0 & 100 & $20.24(32.42)$ & $23.62(34.68)$ \\
\hline Perceived health & 0 & 10 & $5.29(2.26)$ & $5.22(2.41)$ \\
\hline N (Households) & & & 10,205 & 1,361 \\
\hline N (Household-Years) & & & 62,560 & 1,654 \\
\hline $\mathrm{N}$ (Moves) & & & 0 & 1,654 \\
\hline
\end{tabular}

Notes: The entire data set comprises 10,267 SOEP households and 64,214 observations. For continuous variables, means (standard deviations) are displayed. For binary variables, shares are displayed with the reference category 'does not apply' $(=0)$. The columns Stayers and Movers provide descriptive statistics for households who did (not) change their residence from one year to the next between 2001 and 2013.

Source: Own calculation, based on SOEP households 2001-2013 aged 55 or older (household- and year-specific weights applied) 


\section{$4 \quad$ Results}

\section{Cluster analysis}

Table 2 summarises the results of the NMF cluster analysis. The resulting clusters reveal a comprehensive picture on how later life moves are structured in terms of their motivation, distance and destination. It shows the variables which are most associated with the respective clusters. As described in Section 3.2, covariates with high mixture effect coefficients are more relevant in the formation of a cluster than those with lower coefficients. The standardised mixture effect coefficient range from 0 to 1 . In Table 2 they are grouped into high ( 1 to 0.8 ), medium (0.8 to 0.6 ) and low coefficient levels $(0.6$ to 0.4$)$. Four clusters are suggested by the cophenetic correlation coefficient, which measures the reproducibility of the cluster assignment. The cophenetic correlation coefficients when three to seven clusters are chosen are $0.859 ; 0.873 ; 0.867 ; 0.867$ and 0.859 . Brunet et al. (2004) recommend selecting the number of clusters before the cophenetic coefficient begins to fall. This is the case when moving from four to five clusters.

Residential improvement moves are defined by several objective and subjective measures that indicate an upgrade in a household's housing satisfaction. For example, the previous home could have been evaluated as too small or insufficiently equipped, while the new home is larger in size and located in a more suitable neighbourhood. Moves are related to inheritance and home-ownership. The common moving distance of this cluster is 2 to $50 \mathrm{~km}$.

Family moves are defined by moving for family reasons, often closer to children, grandchildren or parents. They are long-distant in nature and correspond to a change in regional structure either from rural to urban or from urban to rural. They also include moves back to one's childhood hometown.

Residential adaptation moves are defined as short-distance moves of less than $2 \mathrm{~km}$, often within urban neighbourhoods with high migrant shares. They are commonly directed towards social housing or other rental apartments as part of a series of moves. Moves due to a notice given by the landlord also fall in this cluster.

Care moves are mainly directed to care facilities or to housing of smaller size accessible to people with disabilities or the elderly. They usually lead to a perceived downgrade in the relation to neighbours and in the satisfaction with the surrounding. Care moves are associated with the former residence being too large or too expensive.

Figure 3 visualises the share of each moving type among all later life moves across age. While residential improvement and family moves contribute more than 50 percent of all later life moves at younger ages, they play a decreasing role at older ages. At age 90, more than half of all residential changes are care moves. Family moves peak at around age 65, the official retirement age in Germany. Family moves and residential adaptation moves peak around age 80 . While the share of family moves decreases after age 65, residential adaptation moves gain in importance. Their share is highest between age 75 and 80 with around one fourth of all later life moves. 
Tab. 2: Results of the NMF clustering algorithm for four clusters

\begin{tabular}{|c|c|c|c|c|}
\hline \multirow[t]{2}{*}{$\begin{array}{l}\text { Mixture Effect } \\
\text { Co-efficients }\end{array}$} & $\begin{array}{l}\text { Residential } \\
\text { improvement } \\
\text { moves }\end{array}$ & Family move & $\begin{array}{c}\text { Residential } \\
\text { adaptation move }\end{array}$ & \multirow[t]{2}{*}{ Care move } \\
\hline & $\begin{array}{c}\text { with } 426 \\
\text { associated moves }\end{array}$ & $\begin{array}{l}\text { with } 398 \\
\text { associated moves }\end{array}$ & $\begin{array}{c}\text { with } 471 \\
\text { associated moves }\end{array}$ & \\
\hline $\begin{array}{l}\text { High } \\
(0.8 ; 1]\end{array}$ & $\begin{array}{l}\text { Increase in } \\
\text { neighbourhood } \\
\text { status; Increase } \\
\text { in living space; } \\
\text { Moved for } \\
\text { job reasons; } \\
\text { Previous housing } \\
\text { too small; } \\
\text { Previous location } \\
\text { not appealing; } \\
\text { Previous } \\
\text { surrounding } \\
\text { not appealing; } \\
\text { Moved because } \\
\text { of an inheritance }\end{array}$ & $\begin{array}{l}\text { Long distance } \\
\text { move (>50km); } \\
\text { From rural to } \\
\text { urban region; } \\
\text { From urban to } \\
\text { rural region; } \\
\text { Move back } \\
\text { to place of } \\
\text { childhood; Move } \\
\text { to children; Move } \\
\text { to grandchildren; } \\
\text { Move to parents; } \\
\text { Moved for family } \\
\text { reasons }\end{array}$ & $\begin{array}{l}\text { Short distance } \\
\text { move }(<2 \mathrm{~km}) ; \\
\text { From urban to } \\
\text { urban region; } \\
\text { Multiple moves } \\
\text { within the past } \\
\text { two years; Notice } \\
\text { given by landlord }\end{array}$ & $\begin{array}{l}\text { Perceived } \\
\text { downgrade in } \\
\text { surrounding; } \\
\text { Perceived } \\
\text { downgrade } \\
\text { in relation to } \\
\text { neighbours; } \\
\text { Decrease in living } \\
\text { space; Move } \\
\text { to care facility; } \\
\text { Previous housing } \\
\text { too expensive; } \\
\text { Previous housing } \\
\text { too big }\end{array}$ \\
\hline $\begin{array}{l}\text { Medium } \\
(0.6 ; 0.8]\end{array}$ & $\begin{array}{l}\text { Move to } \\
\text { ownership; } \\
\text { Previous housing } \\
\text { had low standard }\end{array}$ & & $\begin{array}{l}\text { Previous } \\
\text { neighbourhood } \\
\text { had a high } \\
\text { migrant share; } \\
\text { Moved to social } \\
\text { housing }\end{array}$ & $\begin{array}{l}\text { Housing } \\
\text { accessible } \\
\text { to elderly or } \\
\text { disabled people } \\
\text { needed }\end{array}$ \\
\hline $\begin{array}{l}\text { Low } \\
(0.4 ; 0.6]\end{array}$ & $\begin{array}{l}\text { Medium distance } \\
\text { move }(2-50 \mathrm{~km}) ; \\
\text { From rural to } \\
\text { rural region; } \\
\text { Perceived } \\
\text { upgrade in } \\
\text { surrounding; } \\
\text { Perceived } \\
\text { upgrade in } \\
\text { relation to } \\
\text { neighbours }\end{array}$ & & $\begin{array}{l}\text { Move to apart- } \\
\text { ment (vs. house) }\end{array}$ & $\begin{array}{l}\text { From rural to rural } \\
\text { region }\end{array}$ \\
\hline
\end{tabular}

Notes: Clustering results of 1,654 later life moves between 2001 and 2013 with 100 NMF iterations and four clusters (ranks) specified ex-ante. Covariates with high mixture effect coefficients are more relevant in defining a cluster. All variables are binary with reference category 'does not apply' $(=0)$.

Source: Own calculation, based on SOEP households 2001-2013 aged 55 or older at the year of a residential move $(n=1,654$, unweighted) 
Fig. 3: Distribution of type of later life moves over age

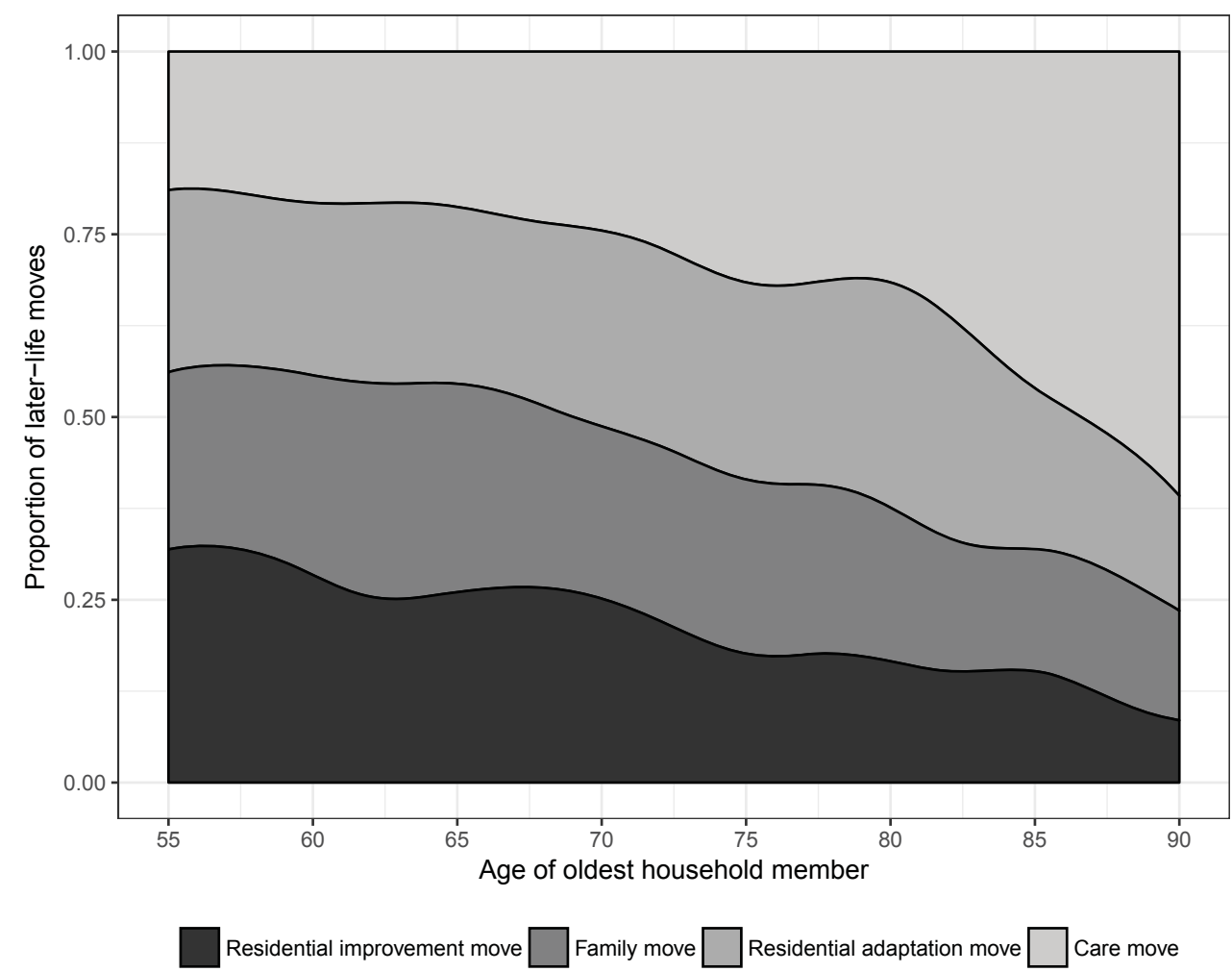

Notes: Proportion of move types among all later life moves. Residential moves are classified according to their strongest association with one of the derived clusters: residential improvement, family, residential adaptation and care. See table 2.

Source: Own calculation, based on SOEP households 2001-2013 aged 55 or older at the year of a residential move $(n=1,654$, unweighted)

\section{Regression analysis}

The regression results in Table 3 reveal general determinants for later life moves. In line with earlier findings, home-owners are less likely to change residence (Tatsiramos 2006). The effect is highly significant and predicts a decrease in moving probability by 0.50 to 1.24 percentage points, holding other predictors constant. Spending more years in the same residence also reduces the probability of moving. Households who moved in the past seem more likely to move in the future. Further drivers include recent widowhood and recent divorce, which increase the probability significantly for almost all types of moves.

Residential improvement moves show no significant effect for partnership status, apart from the reference group of being married. They further relate to households at a younger age and to healthier stages in their later life. This corresponds to the description of amenity moves by Litwak and Longino (1987). In contrast, residential 
Tab. 3: Multinomial logistic regression model

\begin{tabular}{|c|c|c|c|c|}
\hline & $\begin{array}{l}\text { Residential } \\
\text { improvement } \\
\text { move }\end{array}$ & Family move & $\begin{array}{c}\text { Residential } \\
\text { adaptation } \\
\text { move }\end{array}$ & Care move \\
\hline Age & $-0.037^{* * *}$ & $-0.020 * * *$ & -0.006 & $0.009+$ \\
\hline Migration background & 0.001 & -0.077 & $0.200^{*}$ & 0.004 \\
\hline \multicolumn{5}{|l|}{ Married (ref.) } \\
\hline Married in past two years & 0.570 & 0.442 & -0.183 & 0.682 \\
\hline Divorced & 0.125 & $0.288^{* *}$ & 0.136 & $0.540 * * *$ \\
\hline Divorced in past two years & 0.716 & $1.269^{*}$ & $0.874+$ & $0.954+$ \\
\hline Widowed & -0.057 & $0.361 * *$ & -0.002 & $0.466 * * *$ \\
\hline Widowed in past two years & 0.313 & $0.527^{*}$ & $0.472+$ & $1.502^{* * *}$ \\
\hline Unmarried & 0.140 & 0.188 & 0.193 & $0.487^{*}$ \\
\hline Hours spent with childcare & -0.019 & $0.058^{* * *}$ & -0.008 & 0.016 \\
\hline Never had children & 0.023 & $-0.312^{* * *}$ & -0.105 & -0.142 \\
\hline Household income & 0.000 & $0.000 * * *$ & 0.000 & -0.000 \\
\hline Years of education & 0.007 & 0.010 & $-0.031 *$ & 0.003 \\
\hline Periods of unemployment & $-0.039 *$ & -0.006 & 0.005 & 0.009 \\
\hline Exit workforce (ref. employed) & 0.159 & 0.066 & -0.121 & $-0.216^{*}$ \\
\hline Exit workforce in past two years & $0.256+$ & $0.479 * *$ & 0.230 & -0.051 \\
\hline Home-owner prev year & $-0.833^{* * *}$ & $-0.516 * * *$ & $-1.243^{* * *}$ & $-0.498 * * *$ \\
\hline Years in residence prev year & $-0.013^{* * *}$ & $-0.010^{* * *}$ & $-0.015^{* * *}$ & $-0.005^{*}$ \\
\hline Disability degree & 0.001 & $0.002^{*}$ & -0.000 & $0.003 * * *$ \\
\hline Perceived health & 0.016 & -0.001 & -0.007 & $-0.031 *$ \\
\hline LR chi & \multicolumn{4}{|c|}{$1474.35^{* * *}$} \\
\hline McFadden's Adj R2 & \multicolumn{4}{|c|}{0.074} \\
\hline N (Observations) & \multicolumn{4}{|c|}{64,214} \\
\hline $\mathrm{N}$ (Moves) & \multicolumn{4}{|c|}{1,654} \\
\hline
\end{tabular}

Notes: Average marginal effects $(* 100)$ of multinomial logistic model with households as the primary survey unit. The base outcome is no residential move between two survey years. Residential moves are classified according to their strongest association with one of the derived clusters: residential improvement, family, residential adaptation and care. Post-estimations are computed without weights applied. Intercept and indicator variables which capture missing values enter the regressions but are not shown here. The data set comprises 10,267 SOEP households and 64,214 observations. $+p<0.1,{ }^{*} p<0.5, * *$ $\mathrm{p}<0.01,{ }^{* * *} \mathrm{p}<0.001$

Source: Own calculation based on SOEP households $2001-2013$ aged 55 or older $(64,214$ observations, household- and year-specific weights applied) 
improvement moves are not long distance in nature, and are primarily supposed to improve the environmental surrounding. With residential improvement moves, people aim at housing and neighbourhood upgrades within the same region.

Family moves seem to incorporate two lines of motivation. On the one hand, they are a reaction to recent partnership disruption and health decline. Widowhood as a driver for moving closer to one's family has been suggested by Litwak and Longino (1987). According to the three-stage model, comfort moves are related to initial health problems of elderly people who have lost their partner. In the regression model, this can be confirmed, as widowhood and the degree of disability increase the likelihood for family moves significantly. On the other hand, family moves are positively related to a recent exit from the workforce and to hours spent with childcare. This suggests that planned retirement moves are related to the intention to spend more time with. The importance of intergenerational proximity has been highlighted in previous studies (van der Pers et al. 2014; Michielin et al. 2008; Lundholm 2015). Postponed fertility, extended longevity and larger distances between adults and their parents might have led to new moving patterns. For the Netherlands, Smits et al. (2010) found that care needs of grandchildren increase the chance of grandparents moving closer.

Residential adaptation moves are barely affected by long-term singlehood and only weakly significant for recent partnership changes. They are positively related to having a migration background, as well as a lower level of education. Households related to residential adaption moves are the most disadvantaged group in terms of their average level of income, education and unemployment experience (not shown). Earlier research found that they are also the most susceptible groups for (urban) housing stress related to finding apartments, gaining access to social housing, as well as dependence on social welfare (Gestring et al. 2006; Bosch et al. 2010).

For Belgium, Smetcoren et al. (2015) argue that voluntary and involuntary moves are bound to social inequalities. Moving stressors are therefore more prevalent among low-income respondents in poor health, while high-income respondents and home-owners are pulled towards more attractive locations. The types of moves seem to be socially stratified via education, income and employment stability in the past. While the latter factors increase the probability for residential improvement and family moves, education rather hampers residential adaptation moves. ${ }^{2}$

Care moves are positively related to higher ages, furthermore being desabled and reporting lower levels of perceived health are the main factors associated with this type of move. They are further associated with being widowed and being divorced which adds to the high psychological toll preceding a move at very old ages found in earlier studies (Choi et al. 2015). In such cases, health problems often interact with sudden changes in life (such as partnership losses) which require residential adjustments.

2 In a sensitivity analysis (not shown), recent income changes are added to the regression model. No significant effect is estimated as income changes are likely captured by other variables, such as a recent exit from the workforce, widowhood or a divorce. 


\section{Discussion}

The analysis reveals regularities in moving behaviour of elderly people which cannot easily be classified according to age, health status or distant moves. In general, ageing in place is still the most common residential form in Germany, as shown in Figure 2. If moves are driven by pull factors, the results show that they mainly take place around retirement with the goal of upgrading a household's housing situations (residential improvement moves) or being closer to children and grandchildren (family moves). Residential improvement moves are classified as remaining within the same region, which permits the maintenance of social networks (Lundholm 2015). Long distance moves are usually directed towards family members and are related to higher income and a recent retirement. For the German context, amenity-driven moves seem to encompass being close to children and grandchildren, as well as fulfilling longer-term housing aspirations.

A second aspect concerns the importance of linked lives. The concept of linked lives highlights the synchronisation of life trajectories across partners and family members (Elder 2001). Trends towards more liberal gender roles in partnerships and an increased female labour force participation make childcare more dependent on external facilities (Simonson et al. 2011). Earlier research suggests that moving closer to adult children is more likely among elderly parents (Lundholm 2015) in the case of a recent partnership change or childbirth (Michielin et al. 2008). This is in line with the findings of this study. Grandparents may also be willing to provide additional support when employment, income or housing conditions are problematic. Social needs seem to run in two directions, which corresponds to the interpretation of elderly people as both care-givers and care-receivers (Smits 2010).

A third major finding of the analysis are that partnership disruptions can be both triggers and conditions for later life moves. Partnership breakups and widowhood are critical life events which trigger housing and location changes (Bonnet et al. 2010). Their residential implications for a household depend on the socio-economic situation, a household's moving history and the existence of a functional family network. For example, care moves and residential adaptation moves often seem involuntary. Households express lower housing and neighbourhood satisfaction after a care move and after tenancy cancellations by their landlords. In terms of policy recommendations, the results point towards providing adequate long-term care at home, particularly in rural areas (Rude/ et al. 2015) as well as ensuring housing security in urban areas.

There are several weaknesses of the analysis which should be discussed. One point of concern is the construction of variables on the distance to children, grandchildren and parents, which are asked every 5 years starting in 1990. Missing values between two survey years are imputed taking the last valid value in case no move took place and the next valid value in case a move took place. This results in a conservative estimation of the importance of having (grand)children nearby as the measure can remain 0 even if (grand)children are already around.

The SOEP does not track how much time German households spend in other countries during a year if they are still registered in Germany. For the European con- 
text, the role of amenity-rich retirement destinations such as the Mediterranean Sea has been discussed (Breuer 2001). Second homes and lower living expenses give people the opportunity of alternating between houses. Elderly people can spend several months at retirement destinations and stay at the place of residence in Germany for the remaining months of the year. Future research should assess how widespread seasonal residential changes are and if they replace one-time amenity moves within the European context.

For this study, moves to foreign countries are not considered, as such households are not part of the survey. In addition to the 1,654 later life moves considered in this study, 96 households moved to foreign countries, with 79 of them having a migration background. Future research should focus on whether the life course approach on mobility and the synchronisation of life trajectories for elderly movers also apply to return migration by former immigrants.

\section{Conclusion}

Later life migration is a comprehensive term which is often sub-classified according to age, marital status or distance moved. This study argues that such divisions do not fully account for today's patterns of later life migration. A new typology of elderly moves is developed based on observed patterns of move characteristics. Four types are suggested by the results: residential improvement, family, residential adaptation and care moves.

The life course paradigm on mobility facilitates an understanding of the observed patterns. It emphasizes the role of linked lives and the interdependence of life trajectories in the decision to move. More concretely, it embeds the residential choice in a wider social, historical and spatial context. This is valuable when interpreting the effects of partnership disruptions and family ties. Divorced households make up a significant share of later life movers, which relates to a cultural shift towards more independence in the choice of partners. However, partnership disruptions are socially stratified, with diverging effects on residential satisfaction and stability. The findings reveal that family moves towards children are not necessarily health-driven but can also be associated with the existence of grandchildren. Improvements in healthy longevity, urbanisation and increased female labour force participation have led to a situation in which grandparents move closer to their children to act as care-givers, rather than to receive care.

The paradigm's flexibility comes at a cost of not providing clear narratives regarding how changes in the life course translate into residential behaviour. The twofold approach of clustering and regression techniques in the present study derives frequent patterns in later life moves and links them to life course characteristics of households. This helps to reduce the complexity of potential moving behaviour and provides a valuable direction for future research on later life migration. 


\section{References}

Amrhein, Ludwig 2004: Der entstrukturierte Lebenslauf? Zur Vision einer “altersintegrierten" Gesellschaft. In: Journal of Social Policy Research 50,1-2: 147-169.

Angelini, Viola; Laferrère, Anne 2012: Residential mobility of the European elderly. In: CESifo Economic Studies 58,3: 544-569 [doi: 10.1093/cesifo/ifr017].

Bloem, Brigitte; van Tilburg, Theo; Thomése, Fleur 2008: Residential mobility in older Dutch adults: influence of later life events. In: International Journal of Ageing and Later Life 1,3: 21-44 [doi: 10.3384/ijal.1652-8670.083121].

Bonnet, Carole; Gobillon, Laurent; Laferrère, Anne 2010: The effect of widowhood on housing and location choices. In: Journal of Housing Economics 19: 94-108.

Bosch, Mariano; Carnero, M. Angeles; Farré, Lídia 2010: Information and discrimination in the rental housing market: Evidence from a field experiment. In: Regional Science and Urban Economics 40,1: 11-19.

Boschman, Sanne; van Ham, Marten 2015: Neighbourhood selection of Non-Western ethnic minorities: testing the own-group effects hypothesis using a conditional logit model. In: Environment and Planning A 47,5: 1155-1174 [doi: 10.1177/0308518X15592300].

Bradley, Don E. 2011: Litwak and Longino's developmental model of later life migration: evidence from the American Community Survey, 2005-2001. In: Journal of Applied Gerontology 30,2: 141-158.

Breuer, Toni 2001: Altersruhesitze auf den Kanarischen Inseln. Das Beispiel der deutschen Rentner-Residenten. In Freund, Bodo; Jahnke, Holger (Eds.): Der Mediterrane Raum an der Schwelle des 21. Jahrhunderts. Berlin: Geographisches Institut der Humboldt-Universität zu Berlin.

Brown, Lawrence A.; Moore, Eric G. 1970: The intra-urban migration process: a perspective. In: Geografiska Annaler. Series B, Human Geography 52,1: 1-13.

Brunet, Jean-Philippe et al. 2004: Metagenes and molecular pattern discovery using matrix factorization. In: Proc. Natl. Acad. Sci. 101,12: 4164-4169 [doi: 10.1073/ pnas.0308531101].

Bumpass, Larry; Lu, Hsien-Hen 2000: Trends in cohabitation and implications for children`s family contexts in the United States. In: Population Studies 54,1: 29-41.

Cherlin, Andrew J. 2010: Demographic trends in the United States: a review of research in the 2000s. In: Journal of Marriage and Family 72,3: 403-419 [doi: 10.1111/j.17413737.2010.00710.x].

Choi, HwaJung et al. 2015: Older adults' residential proximity to their children: changes after cardiovascular events. In: The Journals of Gerontology Series B: Psychological Sciences and Social Sciences 70,6: 995-1004 [doi: 10.1093/geronb/gbu076].

Clark, William A.V.; Onaka, Jun 1983: Life cycle and housing adjustment as explanations of residential mobility. In: Urban Studies 20,1: 47-57.

Cliquet, Robert 2003: Major trends affecting families in the new millennium: Western Europe and North America. In: Major trends affecting families: a background document. United Nations, New York: 1-26.

Courgeau, Daniel 1995: Migration theories and behavioural models. In: International Journal of Population Geography 1, 19-27. 
De Jong, Gordon F.; Fawcett, James T. 1981: Motivations for migration: an assessment and a value-expectancy research mode. In: De Jong, Gordon F.; Gardner, Robert W. (Eds.): Migration decision making: multi-disciplinary approaches to micro-level studies in developed and developing countries, Pergamon Policy Studies on International Development. New York: Pergamon: 13-58.

De Jong, Gordon F. 2000: Expectations, gender, and norms in migration decision making. In: Population Studies 54,3: 307-319 [doi: 10.1080/713779089].

Dieleman, Frans M.; Clark, William A.V.; Deurloo, Marinus C. 2000: The geography of residential turnover in twenty-seven large US metropolitan housing markets, 1985-95. In: Urban Studies 37,2: 223-245.

DRV 2015: Rentenversicherung in Zeitreihen, 22nd Edition. Berlin: Deutsche Rentenversicherung Bund.

Elder, Glen H. 2001: Life course perspective. In: Ritzer, Georg (Ed.): Blackwell Encyclopedia of Sociology. Massachusetts: Blackwell: 2634-2639.

Elder, Glen H.; Johnson, Monica K.; Crosnoe, Robert 2003: The emergence and development of life course theory. In: Mortimer, Jeylan T.; Shanahan, Michael J. (Eds.): Handbook of the life course. Handbooks of Sociology and Social Research. New York: Kluwer Academic/Plenum Publishers: 3-19.

Feijten, Peteke; van Ham, Marten 2009: Neighbourhood change ... reason to leave? In: Urban Studies 46,10: 2103-2122 [doi: 10.1177/0042098009339430].

Frick, Joachim R. et al. 2012: Familienbiographische Verläufe im Kohortenvergleich. In: SOEPpapers on Multidisciplinary Panel Data Research 439.

Friedrich, Klaus 1995: Altern in räumlicher Umwelt: Sozialräumliche Interaktionsmuster älterer Menschen in Deutschland und in den USA. Vol. 10. Darmstadt: Steinkopff Verlag.

Frigyesi, Attila; Höglund, Mattias 2008: Nonnegative matrix factorization for the analysis of complex gene expression data: identification of clinically relevant tumor subtypes. In: Cancer Informatics 6: 275-292.

Gaujoux, Renaud; Seoighe, Cathal 2010: A flexible R package for nonnegative matrix factorization. In: BMC Bioinformatics 11,1: 367 [doi: 10.1186/1471-2105-11-367].

Gestring, Norbert; Janßen, Andrea; Polat, Ayça 2006: Prozesse der Integration und Ausgrenzung. Türkische Migranten der zweiten Generation. VS Verlag für Sozialwissenschaften: Wiesbaden.

Grabka, Markus 2012: Codebook for the PEQIV File 1984-2011 - CNEF Variables with Extended Income Information for the SOEP. Berlin: Deutsches Institut für Wirtschaftsforschung (DIW).

Goll, Michel 2010: Ageing in the European Union: where exactly? In: Eurostat, Statistics in Focus 26.

Hall, Peter A.; Soskice, David 2001: Varieties of Capitalism. Oxford: Oxford University Press.

Hutchins, Lucie N. et al. 2008: Position dependent motif characterization using nonnegative matrix factorization. In: Bioinformatics 24,23: 2684-2690 [doi: 10.1093/bioinformatics/btn526].

Kley, Stefanie 2011: Explaining the stages of migration within a lifecourse frame work. In: European Sociological Review 27,4: 469-486 [doi: 10.1093/esr/jcq020].

Kroh, Martin 2014: Documentation of sample sizes and panel attrition in the German Socio Economic Panel (SOEP) (1984 until 2012). In: Data Documentation, DIW 71: Berlin. 
Lesthaeghe, Ron 2010: The unfolding story of transition. In: Population and Development Review 36,2: 211-251 [doi: 10.1111/j.1728-4457.2010.00328.x].

Litwak, Eugene; Longino, Charles F. 1987: Migration patterns among the elderly: a developmental perspective. In: The Gerontologist 27,3: 266-272.

Lundholm, Emma 2015: Migration and regional differences in access to local family networks among 60-year olds in Sweden. In: Journal of Population Ageing 8,3: 1-13 [doi: 10.1007/s12062-015-9117-z].

Mahne, Katharina; Huxhold, Oliver 2017: Nähe auf Distanz: Bleiben die Beziehungen zwischen älteren Eltern und ihren erwachsenen Kindern trotz wachsender Wohnentfernungen gut? In: Mahne, Katharina et al. (Eds.): Altern im Wandel: Zwei Jahrzehnte Deutscher Alterssurvey (DEAS). Wiesbaden: Springer Fachmedien Wiesbaden: 215230 [doi: 10.1007/978-3-658-12502-8_14].

Michielin, Francesca; Mulder, Clara H.; Zorlu, Aslan 2008: Distance to parents and geographical mobility. In: Population, Space and Place 14,4: 327-345 [doi: 10.1002/ psp.509].

Mulder, Clara H.; Hooimeijer, Pieter 1999: Residential relocations in the life course. In: Wissen, Leo J.G.; Dykstra, Pearl A.; Land, Kenneth C. (Eds.): Population issues: an interdisciplinary focus. The Springer Series on Demographic Methods and Population Analysis. Springer Netherlands: 159-186.

Rindfuss, Ronald R.; Swicegood, C. Gray; Rosenfeld, Rachel A. 1987: Disorder in the life course: How common and does it matter? In: American Sociological Review 52,6: 785.

Rogers, Andrei 1988: Age patterns of elderly migration: an international comparison. In: Demography 25,3: 355-370.

Rossi, Peter H. 1955: Why families move: a study in the social psychology of urban residential mobility. Free Press: Glencoe.

Rudel, Miriam; Abraham, Martin; Görtler, Edmund 2015: Pflegepräferenzen und regionale Mobilität. In: Zeitschrift Für Gerontologie und Geriatrie: 1-10.

Sander, Nikola et al. 2010: Prospects for later life migration in urban Europe. Tech. rep., PLUREL.

Sander, Nikola; Bell, Martin 2014: Migration and retirement in the life course: an event history approach. In: Journal of Population Research 31,1: 1-27 [doi: 10.1007/s12546013-9121-1].

Simonson, Julia; Gordo, Laura Romeu; Titova, Nadiya 2011: Changing employment patterns of women in Germany: How do baby boomers differ from older cohorts? A comparison using sequence analysis. In: Advances in Life Course Research 16,2: 65-82 [doi: 10.1016/j.alcr.2011.03.002].

Smetcoren, An-Sofie et al. 2015: Refining the push and pull framework: identifying inequalities in residential relocation among older adults. In: Ageing \& Society 37,1: 90 112 [doi: 10.1017/S0144686X15001026].

Smits, Annika 2010: Moving close to parents and adult children in the Netherlands: the influence of support needs. In: Demographic Research 22,31: 985-1013 [doi: 10.4054/ DemRes.2010.22.31].

Smits, Annika; van Gaalen, Ruben I.; Mulder, Clara H. 2010: Parent-child coresidence: who moves in with whom and for whose needs? In: Journal of Marriage and Family 72,4: 1022-1033 [doi: 10.1111/j.1741-3737.2010.00746.x].

Swiaczny, Frank 2010: Implications of demographic change for civil society in Germany. In: Journal of Population Research 27,3: 193-211 [doi: 10.1007/s12546-010-9041-2]. 
Tatsiramos, Konstantinos 2006: Residential mobility and housing adjustment of older households in Europe. IZA Discussion Papers 2435.

United Nations, Department of Economic and Social Affairs, Population Division 2015: World Population Prospects: The 2015 Revision. New York: United Nations.

van der Pers, Marieke; Kibele, Eva U.B.; Mulder, Clara H. 2014: Intergenerational proximity and the residential relocation of older people to care institutions and elsewhere. In: Ageing \& Society 35,7: 1429-1456 [doi: 10.1017/S0144686X14000300].

Wang, Yu-Xiong; Zhang, Yu-Jin 2013: Nonnegative matrix factorization: a comprehensive review. In: IEEE Transactions on Knowledge and Data Engineering 25,6: 1336 1353 [doi: 10.1109/TKDE.2012.51].

Yee, William; van Arsdol, Maurice D. 1977: Residential mobility, age, and the life cycle. In: Journal of Gerontology 32,2: 211-221.

Tim Winke ( $₫)$. Humboldt-Universität zu Berlin, Graduate School of Social Sciences (BGSS). Berlin, Germany. E-mail: tim.winke@hu-berlin.de

URL: https://www.bgss.hu-berlin.de/de/bgss/people/students/tim_winke 


\section{Comparative Population Studies}

wWW.comparativepopulationstudies.de

ISSN: 1869-8980 (Print) - 1869-8999 (Internet)

\section{Published by}

Prof. Dr. Norbert F. Schneider

Federal Institute for Population Research D-65180 Wiesbaden / Germany

\section{(cc) BY-SA}

2017

\section{Managing Editor}

Frank Swiaczny

\section{Assistant Managing Editor}

Katrin Schiefer

\section{Copy Editor}

(Selected Articles in German)

Dr. Evelyn Grünheid

\section{Layout}

Beatriz Feiler-Fuchs

E-mail: cpos@bib.bund.de

\section{Scientific Advisory Board}

Paul Gans (Mannheim)

Karsten Hank (Cologne)

Johannes Huinink (Bremen)

Michaela Kreyenfeld (Rostock)

Marc Luy (Vienna)

Notburga Ott (Bochum)

Peter Preisendörfer (Mainz)

Nikola Sander (Groningen)

Zsolt Spéder (Budapest)

\section{Board of Reviewers}

Martin Abraham (Erlangen)

Laura Bernardi (Lausanne)

Hansjörg Bucher (Bonn)

Claudia Diehl (Konstanz)

Andreas Diekmann (Zurich)

Gabriele Doblhammer-Reiter (Rostock)

Jürgen Dorbritz (Wiesbaden)

Anette Eva Fasang (Berlin)

E.-Jürgen Flöthmann (Bielefeld)

Alexia Fürnkranz-Prskawetz (Vienna)

Beat Fux (Salzburg)

Joshua Goldstein (Berkeley)

Sonja Haug (Regensburg)

Hill Kulu (Liverpool)

Aart C. Liefbroer (The Hague)

Kurt Lüscher (Konstanz)

Emma Lundholm (Umeå)

Nadja Milewski (Rostock)

Dimiter Philipov (Vienna)

Roland Rau (Rostock)

Tomáš Sobotka (Vienna)

Jeroen Spijker (Barcelona)

Olivier Thévenon (Paris)

Helga de Valk (Brussels)

Heike Trappe (Rostock)

Michael Wagner (Cologne) 